\title{
Electron probe analysis of the elemental microenvironment of oviducal mouse embryos
}

\author{
L. Roblero,* J. D. Biggers and C. P. Lechene \\ Department of Physiology and Laboratory of Human Reproduction and Reproductive Biology, \\ Harvard Medical School, 45 Shattuck Street, Boston, Massachusetts 02115, U.S.A.
}

Fertilization in mammals occurs in the ampullary region of the oviduct. The fertilized ovum then undergoes cleavage divisions while passing along the oviduct to the uterus and lying free in the oviducal fluid. At any given time the embryo is surrounded by an oviducal microenvironment with which it interacts by the exchange of substances (Biggers \& Borland, 1976). So far no analyses have been made of these local oviducal microenvironments. By the combined use of micropuncture techniques (Lechene, Morel, Guinnebault \& de Rouffignac, 1969), and X-ray spectrometry by electron probe excitation (Lechene, 1970, 1974), it has been possible to estimate the concentrations of the major elements in the microenvironments of 1- and 2-celled mouse embryos in the ampullary and isthmus regions of the oviduct, respectively. Gonadotrophin-treated immature mice were used in these initial studies since they have thin-walled oviducts which facilitate the development of adequate micropuncture techniques. Such females can give birth to normal young at term, and the rate of tubal transport is approximately the same as that reported in adult females (Humphrey, 1968). Low doses of gonadotrophins do not affect rate of cleavage (Allen \& McLaren, 1971).

Random-bred female Swiss mice, 4 weeks old, were injected i.p. at 12.00 hours with 2.5 i.u. PMSG (NIH). Forty-eight hours later, the mice were injected i.p. with 2.5 i.u. HCG (Sigma) and placed with a male. Ovulation was expected about 24.00 hours and this was taken as the time of fertilization. The presence of a vaginal plug the next morning indicated that mating had occurred. After 10-17 hr ova could be found in a clump in the ampullary region of the oviduct, and $24-41 \mathrm{hr}$ after fertilization 2-celled embryos were present, also in a clump, in the isthmus region. To collect the fluid, the mouse was anaesthetized with tribromoethanol $(50 \mathrm{mg}$ Inactin $/ \mathrm{ml} ; 0 \cdot 12-0.15 \mathrm{ml}$ i.p.), and the hair clipped from the back. The skin was wiped with mineral oil, and the ovary and oviduct were exposed through a dorsolateral incision which was also irrigated with mineral oil. The location of the embryos in the ampulla or isthmus was determined by examining the oviduct with a stereo-microscope. The embryos and their surrounding fluid were withdrawn from the ampulla by inserting a micropipette, tip diameter of 100-150 $\mu \mathrm{m}$, containing mineral oil through the wall and applying controlled suction. A sample was often obtained from both oviducts. The embryos and fluid from the isthmus were obtained in a similar fashion using micropipettes of $100 \mu \mathrm{m}$ tip diameter. All samples grossly contaminated with blood were discarded.

After withdrawal of the pipette, further mineral oil was sucked into the pipette; the tip was closed by heat, avoiding disturbance of the fluid drop containing the embryos, and the pipette centrifuged for $10 \mathrm{~min}$ at $1470 \mathrm{~g}$ at room temperature. The ova and cumulus cells, if present, moved to the tip of the pipette leaving the oviducal fluid above. Samples of ampullary and isthmus fluids not containing embryos were discarded. The part of the pipette containing the cells was then cut off and the oviducal fiuid was placed in a small Petri dish under mineral oil which had been equilibrated with $0.9 \% \mathrm{NaCl}$ in water, and immediately frozen and kept at $-20^{\circ} \mathrm{C}$. The time taken from the withdrawal of the micropipette from the oviduct to freezing the sample of oviducal fluid was about $30 \mathrm{~min}$. The following day the samples were thawed and the concentrations of $\mathrm{Na}, \mathrm{Cl}$, $\mathrm{Ca}, \mathrm{K}, \mathrm{Mg}, \mathrm{S}$ and $\mathrm{P}$ were estimated by $\mathrm{X}$-ray spectrometry with electron probe excitation.

* Present address: Instituto de Ciencias Biologicas, Laboratorio de Embriologia, Universidad Catolica de Chile, Santiago, Chile. 
The preparation and analysis of samples has been described previously (Lechene, 1970, 1974). Briefly, the unknown samples and a series of standard solutions were placed onto the surface of a beryllium support previously coated with mineral oil, using calibrated volumetric pipettes (20-80 pl). These pipettes were made on a de Fonbrune microforge and calibrated with tritiated $\mathrm{H}_{2} \mathrm{O}$. The oil on the beryllium block was removed with a $m$-xylene wash and the sample on the beryllium block immediately frozen in isopentane at $-150^{\circ} \mathrm{C}$. The microdroplets were then freeze-dried under vacuum $\left(10^{-5} \mathrm{mmHg},-70^{\circ} \mathrm{C}\right)$ so that very small crystals (diam. $\left.<1 \mu \mathrm{m}\right)$ were obtained. The beryllium block was rewarmed under vacuum to avoid water condensation when the block was returned to atmospheric pressure. The analyses were performed with a Cameca MS/46 microprobe. The electron accelerating potential was $11 \mathrm{keV}$ and the beam current was fixed at $200 \mathrm{nA}$ on the beryllium. The beam was kept static and the beam diameter adjusted to excite the entire dried sample. X-ray emissions from $\mathrm{Na}$ and $\mathrm{Mg}$ were analysed using potassium acid phthalate diffracting crystals, while $\mathrm{P}, \mathrm{Cl}, \mathrm{K}$ and $\mathrm{Ca}$ required pentaerythritol diffracting crystals. The concentrations of the unknowns were determined with respect to the counts obtained from identical volumes of five standard solutions that contained known amounts of the 7 elements.

Samples of ampullary fluid were obtained from both oviducts of 16 mice, and samples of isthmic fluid from 9 mice. Analyses of variance, for each of the 7 elements in each site, showed that the variation between mothers was significantly greater than that within mothers. Thus the statistical comparison of the concentrations of the different elements between sites has been based on the variation between mothers. Samples of ampullary and isthmic fluid were also obtained from single oviducts of 9 and 8 mice, respectively. Weighted means and their variance-covariance matrices have been calculated for each site from the means of the concentrations in both oviducts/mouse allotting a weight of 2 , and each single oviduct mouse allotting a weight of 1 . The correlation matrices were then calculated from the variance-covariance matrices of the weighted means. Tests of significance were based usually on Student's $t$ test, but when variances of the two means being compared were significantly different the Fisher-Behren's test was used (Fisher \& Yates, 1970). Statistical analyses have been done on the untransformed data, and after transformation to natural logarithms, using a time-sharing system connected to a Hewlett-Packard 2000F computer. The conclusions were the same in both scales and the results are therefore presented using the untransformed data.

The results are summarized in Tables 1 and 2. The mean $K, S$ and $P$ contents of fluid obtained from the isthmus containing 2-celled embryos were statistically significantly higher than the contents of the ampullary fluid containing fertilized ova and follicular cells. There were no significant differences in the concentrations of $\mathrm{Na}, \mathrm{Cl}, \mathrm{Ca}$ and $\mathrm{Mg}$. The $\mathrm{S}$ and $\mathrm{P}$ concentrations represent inorganic phosphate and sulphate, together with organic compounds. The fact that both increase in concentration and that the isthmic fluid is more difficult to pipette because of its viscosity suggests that the protein content of the environment of the embryo increases as it passes along the oviduct. Ampullary and isthmic fluids differ considerably in composition from serum in that they contain significantly more $\mathrm{K}$ and less $\mathrm{Ca}$ and $\mathrm{Mg}$. The oviducal fluids contain significantly less $\mathrm{Na}$, though the differences are relatively small in comparison with the other elements.

Table 1. The weighted mean ( \pm S.E.M., $\mathrm{N}=$ no. of animals) concentrations $(\mathrm{mm} / \mathrm{l})$ of $\mathrm{Na}, \mathrm{Cl}, \mathrm{Ca}$, $\mathrm{K}, \mathrm{Mg}, \mathrm{S}$ and $\mathrm{P}$ in serum and the microenvironments of 1- and 2-celled mouse embryos in the ampulla and isthmus, respectively, of the oviduct

\begin{tabular}{|c|c|c|c|}
\hline Element & Ampulla $(\mathrm{N}=25)$ & Isthmus $(\mathrm{N}=17)$ & Serum $(N=12) \dagger$ \\
\hline $\mathrm{Na}$ & $137 \pm 4 \cdot 78$ & $142 \pm 3 \cdot 42$ & $148 \pm 1 \cdot 72$ \\
\hline $\mathrm{Cl}$ & $147 \pm 4 \cdot 98$ & $145 \pm 6 \cdot 20$ & $140 \pm 2 \cdot 10$ \\
\hline $\mathrm{Ca}$ & $1.62 \pm 0.13$ & $1.48 \pm 0.14$ & $3 \cdot 82 \pm 0.16$ \\
\hline K & $17 \cdot 8 \pm 1 \cdot 38$ & $29.7 \pm 3.63^{*}$ & $5 \cdot 26 \pm 0.15$ \\
\hline $\mathbf{M g}$ & $0.63 \pm 0.08$ & $0.81 \pm 0.07$ & $1 \cdot 38 \pm 0.20$ \\
\hline $\mathbf{S}$ & $5.13 \pm 0.53$ & $9.13 \pm 0.92^{*}$ & $21.8 \pm 0.32$ \\
\hline $\mathbf{P}$ & $3.90 \pm 0.64$ & $8.46 \pm 1.79^{*}$ & $6.97 \pm 0.27$ \\
\hline
\end{tabular}

* Significantly different $(P<0.01)$ from the concentration in ampullary fluid (Fisher-Behren's test). All other comparisons are not statistically significant at the $P=0.05$ level.

$\dagger$ Unpublished results of R. M. Borland, S. Hazra, J. D. Biggers and C. P. Lechene. 
Table 2. The correlation matrices of the weighted means of the concentrations of $\mathrm{Na}, \mathrm{Cl}, \mathrm{Ca}, \mathrm{K}, \mathrm{Mg}, \mathrm{S}$ and $\mathbf{P}$ in the microenvironments of 1- and 2-celled mouse embryos in the ampulla and isthmus, respectively, of the oviduct $(\mathrm{N}=$ no. of animals)

\begin{tabular}{|c|c|c|c|c|c|c|}
\hline & & & npulla (1 & & & \\
\hline $\mathrm{Na}$ & $\mathrm{Cl}$ & $\mathrm{Ca}$ & K & $\mathbf{M g}$ & $\mathbf{S}$ & $\mathbf{P}$ \\
\hline \multirow[t]{6}{*}{1} & $0.805^{*}$ & $0.726^{*}$ & -0.135 & 0.150 & -0.003 & -0.248 \\
\hline & 1 & $0.599^{*}$ & 0.062 & $0 \cdot 133$ & -0.031 & -0.137 \\
\hline & & 1 & 0.027 & $0 \cdot 220$ & -0.093 & -0.116 \\
\hline & & & 1 & $0.732^{*}$ & $0.634^{*}$ & $0.807^{*}$ \\
\hline & & & & 1 & $0.521^{*}$ & $0.573^{*}$ \\
\hline & Sym & & & & 1 & $0.817^{*}$ \\
\hline
\end{tabular}

\begin{tabular}{|c|c|c|c|c|c|c|}
\hline \multicolumn{7}{|c|}{ Isthmus $(\mathrm{N}=17)$} \\
\hline $\mathrm{Na}$ & $\mathrm{Cl}$ & $\mathrm{Ca}$ & $\mathbf{K}$ & $\mathbf{M g}$ & $\mathbf{S}$ & $\mathbf{P}$ \\
\hline \multirow[t]{7}{*}{1} & $0 \cdot 511^{* *}$ & $0.626^{*}$ & $-0 \cdot 214$ & -0.097 & $-0 \cdot 409$ & -0.152 \\
\hline & 1 & 0.331 & $0.572^{* *}$ & 0.277 & 0.425 & $0.612^{*}$ \\
\hline & & 1 & -0.038 & 0.274 & $-0 \cdot 138$ & -0.027 \\
\hline & & & 1 & $0.693^{*}$ & $0.929^{*}$ & $0.963^{*}$ \\
\hline & & & & 1 & $0.615^{*}$ & $0.670^{*}$ \\
\hline & Sym & & & & 1 & $0.865^{*}$ \\
\hline & & & & & & 1 \\
\hline
\end{tabular}

The results provide the first chemical analyses of the microenvironment of the preimplantation mammalian embryo and show that the oviducal fluid is characterized by high concentrations of $\mathrm{K}$ and low concentrations of $\mathrm{Ca}$, and changes as the embryo passes from the ampulla to the isthmus.

It is possible that contamination of the sample with tissue fluid and damaged cells could occur during the course of micropuncture. The analyses of variance show, however, that variation from this cause is considerably less than the natural variation between mothers. Concentration during the handling of the samples could cause overestimation of their elemental content. Since within a sample the concentrations of all elements would be affected equally, there would be a tendency for the coefficients of correlation between all pairs of elements to be significantly positive. This effect is not seen in the two correlation matrices shown in Table 2.

The results raise several important questions: e.g. what is the physiological role of these concentrations of elements in the development of the embryo, and what are the relative contributions of the embryos and mother via secretions or degenerating cumulus cells in determining the concentrations of elements in the neighbourhood of the embryos? A few clues in the literature suggest these questions are worthy of further systematic study. Tantayaporn, Mallikarjuneswara, De Carlo \& Clemetson (1974) have shown in the rat that oestrogens and progesterone can jointly raise the concentration of $\mathrm{K}$ in uterine secretions comparable to those in the mouse oviduct in early pregnancy. Toyoda \& Chang (1974) have demonstrated that rat sperm capacitation is accelerated in a medium with a high $\mathrm{K} / \mathrm{Na}$ ratio. Furthermore, Brunton \& Brinster (1971) have shown that the ampullary region of the rabbit oviduct actively transports $\mathrm{Na}$ and $\mathrm{Cl}$. Finally, McMahon (1974) has marshalled evidence that ions may play a critical role in the control of embryonic development. Further studies on these problems are in progress.

The work reported in this paper has been supported by grants from the Ford Foundation (720-0369), the Rockefeller Foundation (RF-65040), the Population Council (M74.33), the National Institutes of Health (RO1-HL-15552-03 and PO 7-RROO679-02) and the National Institute of Child Health and Human Development (HD-06916-01A1); L.R. was supported by a grant to the Universidad Catolica de Chile by the Ford Foundation. 


\section{References}

Allen, J. \& Mclaren, A. (1971) Cleavage rate of mouse eggs from induced and spontaneous ovulation. J. Reprod. Fert. 27, 137-140.

Biggers, J.D. \& Borland, R.M. (1976) Physiological aspects of growth and development of the preimplantation mammalian embryo. A. Rev. Physiol. 38, (In press).

Brunton, W.J. \& Brinster, R.L. (1971) Active chloride transport in the isolated rabbit oviduct. Am. J. Physiol. 221, 658-661.

FISHER, R.A. \& YATES, F. (1970) Statistical Tables for Biological, Agricultural and Medical Research, 6th edn. Hafner Publishing Co., Darien, Connecticut.

HumphreY, K.W. (1968) Observations on transport of ova in the oviduct of the mouse. $J$. Endocr. 40, 267-273.

LECHENe, C.P. (1970) The use of electron microprobe to analyse very minute amounts of liquor samples. Proc. 5th Natn. Conf. Electron Probe Analysis, pp. 32A-32C.
LECHENE, C.P. (1974) Electron probe microanalysis of picoliter liquid samples. In Microprobe Analysis as Applied to Cells and Tissues, pp. 351-368. Eds T. Hall, P. Echlin \& R. Kaufmann. Academic Press, New York.

Lechene, C.P., Morel, F., Guinnebault, M. \& DE RoufFIGNAC, D. (1969) Étude par microponction de l'elaboration de l'urine. I. Chez le rat dans différents états de diurèse. Nephron 6, 457-477.

MCMAHON, D. (1974) Chemical messengers in development: a hypothesis. Science, N.Y. 185, 1012-1021.

Tantayaporn, P., Mallikaruuneswara, V.R., De Carlo, S.J. \& Clemetson, C.A.B. (1974) The effects of estrogen and progesterone on the volume and electrolyte content of the uterine luminal fluid of the rat. Endocrinology 95, 1034-1045.

Toyoda, Y. \& Chang, M.C. (1974) Capacitation of epididymal spermatozoa in a medium with high $\mathrm{K} / \mathrm{Na}$ ratio and cyclic AMP for the fertilization of rat eggs in vitro. J. Reprod. Fert. 36, 125-134.

Received 24 July 1975 